\title{
The effects of instant noodles waste in diets for broiler chickens
}

Lala A.O., Oso, A. O., Fafiolu, A. O., Bamgbose, A. M., Eruvbetine, D. and Bemj i, M.

${ }^{1}$ Department of Animal Nutrition, University of Agriculture, P.M.B. 2240 Abeokuta, Nigeria.

${ }^{2}$ Department of Animal Breeding and Genetics, University of Agricul ture, P.M.B. 2240 Abeokuta, Nigeria.

*Author for correspondence: e-mail: funmilala02@yahoo.com

\begin{abstract}
The effects of instant noodles waste (INW) as a replacement for maize was investigated using 144 day-old, unsexed broiler chicks of Anak strain which were randomly assigned into four dietary treatment groups of 36 birds each. Each dietary treatment group had 3 replicates of 12 broilers per replicate. These four different diets were fed, in which INW replaced maize at 0\% (control), 10, 20 and $30 \%$ from day old to 8 weeks of age. The growth performance, nutrient digestibility, haematological parameters and carcass traits of the chickens were evaluated. Average final live weight ranged from $1559.44 \mathrm{~g}$ to $1730.91 \mathrm{~g}$ with broilers fed control diet and $30 \% \mathrm{INW}$ diet recording the highest and least values respectively among the treatments. Broilers fed the $30 \%$ INW had lower $(P<0.05)$ live weight. Broilers fed INW based diets had higher blood profile comparable to the control. The results indicated that INW can replace up to $20 \%$ of broiler starter diet and $30 \%$ replacement of maize at the finisher phase without adverse effects on growth performance of the broilers.
\end{abstract}

Keywords: Instant noodles waste, diets, broilers chickens.

\section{Introduction}

The rapid population growth in Africa which was estimated to be 871 million people in 2004 (Gueye, 2007), This growth is characterized by increasing pressure on food resources most especially cereal grains. Maize is a major source of energy for poultry consisting of about $50-60 \%$ of the total diet (Cowieson, 2005). Maize is keenly competed for by man, industries and livestock resulting in an inadequate supply of maize for use in poultry diets. Poultry nutritionists have tried to harness industrial by products and wastes which are not directly utilized by man and less expensive for the feeding of livestock.

One of such wastes from food processing plant is the instant noodles waste. Instant noodles is fast becoming a staple meal in
Nigeria, according to WINA (2010), the national trend in instant noodles demand in Nigeria has increased from 1080 million tons in 2007 to 1600 million in 2009. As the production of instant noodles increased, higher quantity of waste is being generated in form of trimmings. The proximate composition of instant noodles showed it to contain $15.77 \mathrm{MJ} / \mathrm{kg}$ metabolizable energy, $8.97 \%$ crude protein, $2.80 \%$ crude fibre, $17.14 \%$ ether extract and $0.9 \%$ ash. Instant noodles (produced from wheat) are suitable energy source because of its high energy and oil content. A strong negative correlation between the non starch polysaccharides in wheat, growth performance and nutrient digestibility of poultry has been reported in previous studies (Gracia et al., 2003; Santos et al., 
2004). However, the processing methods employed in the production of instant noodles waste is expected to deal with the NSP effect and improved its utilization in poultry nutrition. The purpose of this study was to evaluate the effect of INW on the growth performance, nutrient digestibility and carcass traits in broilers.

\section{Materials and Methods \\ Processing of instant noodles}

Instant noodles are produced from wheat flour, alkaline ingredients and refined palm oil. The first stage in instant noodles production is the mixing of the wheat flour with alkaline ingredient (sodium carbonate, iron, folacin, riboflavin) to make a homogenous mixture. The mixture is passed through a presser to form noodles sheets, the instant noodles sheets are later sent to the slitter for slicing while the wet trimmings are discarded. The noodles were later passed to the steamer where they are pasteurized under temperature of about 900 $970^{\circ} \mathrm{C}$ and sent into cutters where they are folded into desired shapes.

\section{Experimental design}

Four experimental diets were formulated with INW replacing maize at $0,10,20$ and $30 \%$ of the diets respectively for the starter ( $0-4$ weeks) and finisher (5-8weeks) phases of the experiment. Experimental diets were formulated to meet the NRC requirements (NRC, 1994) for the starter and finisher phases of broiler. One hundred and fortyfour (144) unsexed, day old broilers of Anak strain were used for the experiment Thirty six (36) birds were assigned to each dietary group replicated three times with of 12 birds per replicate. The experimental diets for the starting and finishing phases are shown in Table 2 and 3 respectively. Strict hygiene was maintained during the experimental period while scheduled vaccinations and necessary medications were administered as at when due.

\section{Data collection}

\section{Growth performance}

At the end of each week, the birds were weighed and the feed consumption recorded for each replicate throughout the period of the experiment. The weight gained and feed conversion ratios were calculated from the data. Mortality were recorded as they occurred during the experiment.

\section{Nutrient digestibility}

Apparent digestibilities of dry matter, crude fibre, crude protein, ether extract, ash retention and gross energy of the diets were measured at the end of the starter, grower and finisher phases of the experiments by total collection method (Bourdillon et al., 1990). One bird per replicate was randomly selected and housed in clean and disinfected individual cages for a 3-day adaptation period, one day fasting to empty their digestive tract and daily total excreta collection period for three consecutive days. During the adaptation period, feed and water were supplied ad libitum. At the termination of 24 hour starvation period, the birds were given known quantities of feed. Droppings were collected on 24 hour basis for three days, dried and samples were ground for subsequent analyses to determine the dry matter, crude fibre, crude protein, ether extract and ash digestibilities as described by AOAC (1995).

\section{Haematological and serum parameters}

At the end of each phase of the experiments, one bird per replicate was randomly selected for the collection of blood analysis. Blood was collected from the wing vein. A total of $5 \mathrm{ml}$ blood samples was collected from each bird such that $2.5 \mathrm{ml}$ was collected into bijour bottle treated with ethylene diamine tetra acetic acid (EDTA) for haematological assay, Packed Cell Volume (PCV), Haemoglobin ( $\mathrm{Hb})$, Red 
Table 1. Composition of broiler diets

\begin{tabular}{|c|c|c|c|c|c|c|c|c|}
\hline \multirow[b]{3}{*}{ INGREDIENTS } & \multicolumn{8}{|c|}{ Replacement levels of instant noodles waste (\%) } \\
\hline & \multicolumn{3}{|c|}{ Starter phase } & \multicolumn{3}{|c|}{ Finisher phase } & \multirow[b]{2}{*}{20} & \multirow[b]{2}{*}{30} \\
\hline & 0 & 10 & 20 & 30 & 0 & 10 & & \\
\hline Maize & 50.00 & 40.00 & 30.00 & 20.00 & 50.00 & 40.00 & 30.00 & 20.00 \\
\hline Noodles waste & 0.00 & 10.00 & 20.00 & 30.00 & 0.00 & 10.00 & 20.00 & 30.00 \\
\hline Fish meal $(72 \% \mathrm{CP})$ & 3.50 & 3.50 & 3.50 & 3.50 & 2.50 & 2.50 & 2.50 & 2.50 \\
\hline Soybean meal & 18.00 & 18.00 & 18.00 & 18.00 & 15.70 & 15.70 & 15.70 & 15.70 \\
\hline Groundnut cake & 12.70 & 12.70 & 12.70 & 12.70 & 10.00 & 10.00 & 10.00 & 10.00 \\
\hline Wheat offal & 11.00 & 11.00 & 11.00 & 11.00 & 17.00 & 17.00 & 17.00 & 17.00 \\
\hline Bone meal & 2.50 & 2.50 & 2.50 & 2.50 & 2.50 & 2.50 & 2.50 & 2.50 \\
\hline Oyster shell & 1.50 & 1.50 & 1.50 & 1.50 & 1.50 & 1.50 & 1.50 & 1.50 \\
\hline Lysine & 0.20 & 0.20 & 0.20 & 0.20 & 0.20 & 0.20 & 0.20 & 0.20 \\
\hline Methionine & 0.10 & 0.10 & 0.10 & 0.10 & 0.10 & 0.10 & 0.10 & 0.10 \\
\hline Starter premix & 0.25 & 0.25 & 0.25 & 0.25 & 0.25 & 0.25 & 0.25 & 0.25 \\
\hline \multirow{2}{*}{ Salt } & 0.25 & 0.25 & 0.25 & 0.25 & 0.25 & 0.25 & 0.25 & 0.25 \\
\hline & 100.00 & 100.00 & 100.00 & 100.00 & 100.00 & 100.00 & 100.00 & 100.00 \\
\hline \multicolumn{9}{|l|}{$\begin{array}{l}\text { Determined an alysis } \\
(\%)\end{array}$} \\
\hline Dry matter & 85.50 & 84.50 & 82.50 & 82.50 & 93.00 & 92.50 & 91.00 & 90.50 \\
\hline Crude protein & 22.64 & 22.30 & 22.29 & 21.70 & 20.59 & 20.41 & 20.23 & 20.05 \\
\hline Crude fibre & 3.86 & 4.10 & 4.20 & 4.35 & 4.05 & 4.29 & 4.31 & 4.67 \\
\hline Ether extract & 14.50 & 15.00 & 16.00 & 16.50 & 18.50 & 18.50 & 20.00 & 20.50 \\
\hline Ash & 8.00 & 7.00 & 8.50 & 7.50 & 9.00 & 9.00 & 8.50 & 7.50 \\
\hline Calcium (\%) & 1.61 & 1.61 & 1.62 & 1.62 & 1.62 & 1.62 & 1.63 & 1.63 \\
\hline Phosphorus (\%) & 0.74 & 0.74 & 0.75 & 0.75 & 0.90 & 0.91 & 0.91 & 0.91 \\
\hline Gross Energy (MJ/kg) & 16.40 & 16.78 & 17.07 & 17.53 & 16.57 & 16.78 & 17.21 & 17.82 \\
\hline \multirow{2}{*}{$\begin{array}{l}\text { *Metabolizable } \\
\text { energy }(\mathrm{MJ} / \mathrm{kg})\end{array}$} & 11.78 & 11.79 & 11.79 & 11.80 & 11.99 & 12.00 & 12.01 & 12.02 \\
\hline & & & & & & & & \\
\hline
\end{tabular}

*Calculated

Premix supplied per. kg of feed: Vit.A 4,000,000iu, Vit.D ${ }_{3} 1,200,000 \mathrm{iu}$, Tocopherols $8000 \mathrm{iu}$, Vit.k, $1000 \mathrm{mg}$, Folacin $400 \mathrm{mg}$, Copper $2500 \mathrm{mg}$. Iodine $400 \mathrm{mg}$, Colbalt $80 \mathrm{mg}$, Calcium Panthothenate $3500 \mathrm{mg}$, Pyridoxine $1500 \mathrm{mg}$, Cyanocolabamin $7.5 \mathrm{mg}$, Biotin 3mg, Thiamine $900 \mathrm{mg}$, Riboflavin $1800 \mathrm{mg}$, Niacin 12,500mg, Manganese 40,000mg, Zinc 25,000mg, Iron 15,000mg, Choline chloride 200,000mg, Selenium $35 \mathrm{mg}$, BHT $25,000 \mathrm{mg}$, Anticaking agent $6000 \mathrm{mg}$ 
blood cell (RBC) and White blood cell (WBC). The remaining half of the blood samples were collected in bottles without EDTA and allowed to coagulate to produce sera for blood chemistry measurements (Total Serum Protein (TSP), Uric acid, Creatinine, Albumin, Globulin, Cholesterol and Glucose).

The PCV was determined using Wintrobes microhaematocrit, $\mathrm{Hb}$ concentration was measured by the cyanmethaemoglobin method, RBC and WBC were determined using and improved Neubauer haemocytometer as described by Baker and Silverton (1985). Albumin was determined using the method of Grant et al. (1987), TSP was done using the Biuret method according to Weichselbaum (1952), Uric acid was determined using enzymatic colorimetric method by Fossati et al. (1980), Creatinine was determined by the Colorimetric method of Henry (1974), Glucose was determined according to the method of Barham and Trinder (1972) and
Cholesterol was measured using the method of Roeschlau et al. (1974).

\subsubsection{Carcass characteristics}

At the termination of the experiment, one bird per replicate whose weight is a true representation of mean body weight of birds in each pen was selected for carcass analysis. The birds were deprived of feed overnight before slaughter but had access to water. The carcasses were eviscerated and dissected according to the methods by Jones (1984). The weights of the cut-up parts (head, neck, thighs, drumsticks, breast, back, wings and shanks) and organs (liver, heart, lungs and kidney) were taken using a sensitive scale and expressed as percentage of live weights.

\section{Statistical Analysis}

Data obtained were subjected to Analysis of Variance (ANOVA) using the General Linear Model of SAS software (SAS, 1999). Treatment means were separated by Duncan Multiple Range Test (Duncan, 1955).

Table 2: Performance characteristics of broilers fed INW-based diet

\begin{tabular}{|c|c|c|c|c|c|}
\hline \multirow[t]{2}{*}{ Parameters } & \multicolumn{5}{|c|}{ Instant noodles waste inclusion levels } \\
\hline & $0 \%$ & $10 \%$ & $20 \%$ & $30 \% \quad \mathrm{~S}$ & \\
\hline \multicolumn{6}{|l|}{ Starter phase } \\
\hline Average initial liveweight ( $\mathrm{g}$ bird) & 38.75 & 39.31 & 38.33 & 37.78 & 0.26 \\
\hline Average final weight ( $\mathrm{g} / \mathrm{bird}$ ) & $634.85^{\mathrm{a}}$ & $641.67^{9}$ & $628.80^{\mathrm{a}}$ & $580.56^{b}$ & 8.99 \\
\hline Average body weight gain (g/bird) & $596.10^{\mathrm{a}}$ & 602.36 & $590.45^{\mathrm{a}}$ & $542.78^{b}$ & 8.95 \\
\hline Average total feed intake ( $\mathrm{g} /$ bird) & $1394.85^{\mathrm{a}}$ & $1333.35^{b}$ & $1320.86^{\mathrm{C}}$ & $1299.61^{\circ}$ & 11.70 \\
\hline Daily protein intake (g/bird) & $11.22^{\mathrm{a}}$ & $10.64^{b}$ & $10.32^{c}$ & $10.21^{\mathrm{C}}$ & 0.12 \\
\hline Feed conversion ratio & 2.34 & 2.22 & 2.20 & 2.40 & 0.03 \\
\hline Protein efficiency ratio & 1.90 & 202 & 2.05 & 1.90 & 0.03 \\
\hline \multicolumn{6}{|l|}{ Finisher phase } \\
\hline Average initial liveweight ( $\mathrm{g} / \mathrm{bird}$ ) & 634.85 & 641.67 & 628.79 & 580.56 & 8.94 \\
\hline Average final weight ( $\mathrm{g} / \mathrm{bird})$ & $1730.91^{\mathrm{a}}$ & $1613.89^{4}$ & $1700.96^{\mathrm{a}}$ & $1569.44^{\mathrm{b}}$ & 31.30 \\
\hline Average body weight gain (g/bird) & $1096.06^{\mathrm{a}}$ & $958.33^{\mathrm{c}}$ & $1094.39^{\mathrm{a}}$ & $988.89^{b}$ & 27.30 \\
\hline Average total feed intake (g/bird) & $3110.40^{\mathrm{a}}$ & $2831.11^{\mathrm{c}}$ & $2992.68^{\mathrm{b}}$ & $2836.40^{c}$ & 39.90 \\
\hline Daily protein intake (g/bird) & $23.60^{\mathrm{a}}$ & $20.64^{\circ}$ & $21.62^{b}$ & $20.31^{\mathrm{c}}$ & 0.42 \\
\hline Feed conversion ratio & 2.84 & 2.91 & 2.82 & 2.88 & 0.05 \\
\hline Protein efficiency ratio & 1.66 & 1.68 & 1.77 & 1.74 & 0.04 \\
\hline
\end{tabular}

${ }_{\text {bic }}$ Means on the same row having different superscript are significantly $(\mathrm{P}<0.05)$ different 


\section{Results}

The growth response of starting and finishing broilers fed instant noodles wastebased diets is shown in Table 2 .

Average final live weight and average body weight gain were similar $(\mathrm{P}>0.05)$ for birds fed the control diets, 10 and $20 \%$ INW based-diets while there was a reduction $(\mathrm{P}<$ $0.05)$ in these parameters for birds fed $30 \%$ INW based-diets. Feed intake of the starter broilers reduced $(\mathrm{P}<0.05)$ significantly with increasing dietary inclusion of INW. Feed conversion ratio and protein efficiency ratio were not affected $(\mathrm{P}>0.05)$ by dietary inclusion of INW in all phases of the study. At the finisher phase however, all the parameters measured with the exception of feed intake and protein intake were not affected $(\mathrm{P}>0.05)$. Feed intake at the finishing phase was lower for broilers fed with INW based-diets than those fed with control diets. Protein intake at the finishing phase also followed similar trend with the feed intake.

Table 3 revealed the nutrient digestibility of broilers fed INW based diet. Dry matter digestibility decreased with increase in dietary inclusion of INW at the starter phase. Broilers fed control diets recorded the highest $(\mathrm{P}<0.05)$ value of $81.63 \%$ while birds fed $30 \%$ INW diet recorded the least dry matter digestibility value of $75.91 \%$. Dry matter digestibility however was not affected by dietary treatments at the finisher stage. Crude fibre digestibility decreased ( $\mathrm{P}$ $<0.05$ ) as INW inclusion in the diets increased.

The serum and haematological indices of broilers placed on INW based diet is shown in Table 4. At the starter phase, packed cell volume (PCV) increased $(\mathrm{P}<0.05)$ as the level of INW inclusion in the diet increased. Red blood cell (RBC), white blood cell(WBC), haemoglobin (Hb), total serum protein (TSP), serum uric acid and serum creatinine were not significantly affected

Table 3: Nutrient digestbility of broilers fed instant noodles waste-based diets

\begin{tabular}{|c|c|c|c|c|c|}
\hline \multirow[t]{2}{*}{ Parameters (\%) } & \multicolumn{5}{|c|}{ Instant noodles waste inclusion levels } \\
\hline & $0 \%$ & $10 \%$ & $20 \%$ & $30 \%$ & SEM \\
\hline Starter phase & 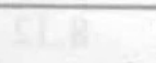 & & 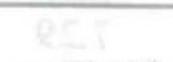 & & \\
\hline Dry matter digestibility & $81.63^{\mathrm{a}}$ & , $80.07^{b}$ & $78.22^{c}$ & $75.91^{\mathrm{c}}$ & 0.77 \\
\hline Nitrogen retention & 84.36 & 83.58 & 79.47 & 81.62 & 1.03 \\
\hline Crude fibre digestibility & $67.87^{\mathrm{a}}$ & $65.30^{\mathrm{a}}$ & $67.24^{\mathrm{a}}$ & $59.35^{b}$ & 1.62 \\
\hline Ash retention & 83.89 & 82.52 & 79.78 & 77.77 & 1.82 \\
\hline $\begin{array}{l}\text { Ether extract digestibility } \\
\text { Finisher phase }\end{array}$ & 91.03 & 9039 & 91.99 & 92.33 & 0.40 \\
\hline Dry matter digestibility & 84.38 & 83.18 & 83.26 & 83.15 & 0.78 \\
\hline Nitrogen retention & 83.80 & 82.65 & 83.02 & 80.97 & 1.01 \\
\hline Crude fibre digestibility & $71.93^{\mathrm{a}}$ & $66.33^{\mathrm{b}}$ & $62.68^{c}$ & $60.30^{c}$ & 1.58 \\
\hline Ash retention (C) & $76.87^{\circ}$ & $80.30^{\mathrm{a}}$ & $73.15^{\mathrm{c}}$ & $74.62^{c}$ & 0.99 \\
\hline Ether extract digestibility & 71.91 & 71.80 & 75.70 & 72.13 & 1.43 \\
\hline
\end{tabular}


Table 4: Serum and haematological parameters of broilers fed INW-based diets

\begin{tabular}{lrrrrr}
\hline Parameters & \multicolumn{5}{c}{ Instant noodles waste inclusion levels } \\
& $0 \%$ & $10 \%$ & $20 \%$ & $30 \%$ & SEM \\
\hline Starter phase & & & & & \\
Packed cell volume $(\%)$ & $27.67^{\mathrm{c}}$ & $29.67^{\mathrm{b}}$ & $29.00^{\mathrm{b}}$ & $32.00^{\mathrm{a}}$ & 0.53 \\
Red blood cell $\left(\times 10^{6} / \mathrm{mm}^{3}\right)$ & 3.53 & 3.40 & 3.27 & 3.87 & 0.09 \\
White blood cell $\left(\times 10^{9} / \mathrm{l}\right)$ & 5.87 & 6.00 & 5.96 & 6.20 & 0.05 \\
Haemoglobin $(\mathrm{g} / \mathrm{dl})$ & 11.13 & 10.10 & 10.00 & 10.97 & 0.24 \\
Total serum protein $(\mathrm{mg} / \mathrm{dl})$ & 40.00 & 40.33 & 39.67 & 38.67 & 0.31 \\
Serum uric ac id $(\mathrm{mg} / \mathrm{dl})$ & 1.37 & 1.37 & 1.36 & 1.36 & 0.01 \\
Finisher phase & & & & & \\
Packed cell volume $(\%)$ & $30.67^{\mathrm{c}}$ & $32.33^{\mathrm{b}}$ & $30.67^{\mathrm{c}}$ & $34.33^{\mathrm{a}}$ & 0.54 \\
Red blood cell $\left.\left(\times 10^{6} / \mathrm{mm}\right)^{3}\right)$ & $3.27^{\mathrm{d}}$ & $3.57^{\mathrm{c}}$ & $3.73^{\mathrm{b}}$ & $3.97^{\mathrm{a}}$ & 0.08 \\
White blood cell $\left(\times 10^{9} / \mathrm{l}\right)$ & 5.90 & 6.07 & 6.33 & 6.10 & 0.03 \\
Haemoglobin $(\mathrm{g} / \mathrm{dl})$ & $11.10^{\mathrm{b}}$ & $10.30^{\mathrm{c}}$ & $11.03^{\mathrm{b}}$ & $11.87^{\mathrm{a}}$ & 0.19 \\
Total serum protein $(\mathrm{mg} / \mathrm{dl})$ & $45.67^{\mathrm{c}}$ & $50.67^{\mathrm{b}}$ & $50.33^{\mathrm{b}}$ & $55.33^{\mathrm{a}}$ & 1.07 \\
Serum uric ac id $(\mathrm{mg} / \mathrm{dl})$ & $3.57^{\mathrm{d}}$ & $3.97^{\mathrm{b}}$ & $3.80^{\mathrm{c}}$ & $4.17^{\mathrm{a}}$ & 0.07 \\
\hline
\end{tabular}

${ }^{a b c}$ Means on the same row having different superscript are significantly $(\mathrm{P}<0.05)$ different

Table 5: Carcass yield of broilers fed instan t noodles waste-based diets Instant noodles waste inclusion levels (\%)

\begin{tabular}{llllll} 
Parameters & 0 & 10 & 20 & 30 & SEM \\
\hline Live-weight (g) & 1800.00 & 1833.33 & 1783.33 & 1733.33 & 38.1 \\
Dressed weight (\%) & $1611.9^{\mathrm{a}}$ & $1645.96^{\mathrm{a}}$ & $1612.67^{\mathrm{b}}$ & $1562.60^{\mathrm{b}}$ & 30.16 \\
Intestine (\%) & 8.53 & 8.35 & 9.19 & 9.49 & 0.40 \\
Thighs (\%) & 11.14 & 10.44 & 10.85 & 11.04 & 0.32 \\
Drumsticks (\%) & 8.96 & 9.56 & 9.75 & 8.87 & 0.35 \\
Wings (\%) & 7.29 & 7.79 & 8.12 & 7.89 & 0.25 \\
Breast (\%) & 15.87 & 18.78 & 16.17 & 16.93 & 0.80 \\
Back (\%) & 12.08 & 11.87 & 13.00 & 13.72 & 0.47 \\
Empty gizzard (\%) & 2.55 & 2.37 & 2.58 & 2.22 & 0.10 \\
Liver (\%) & 2.09 & 2.03 & 1.93 & 2.00 & 0.03 \\
Heart (\%) & 0.44 & 0.48 & 0.48 & 0.47 & 0.02 \\
Abdominal fat (\%) & 0.43 & 0.49 & 0.48 & 0.50 & 0.02 \\
\hline
\end{tabular}

${ }^{a b c}$ Means on the same row having different superscript are signi ficantly $(\mathrm{P}<0.05)$ different

$(\mathrm{P}>0.05)$ by the dietary treatment. However at the finishing phase, packed cell volume (PCV), RBC, $\mathrm{Hb}$ and TSP were significantly $(\mathrm{P}<0.05)$ affected by the dietary treatment. Finishing broilers fed with $30 \%$ INW based-diets recorded the highest $(\mathrm{P}<0.05) \mathrm{PCV}, \mathrm{RBC}, \mathrm{Hb}$ and TSP values.

Carcass yield as shown in Table 5 indicated no significant $(\mathrm{P}>0.05)$ difference across the treatment levels for all the parameters measured with the exception of the dressed weight which was significantly $(\mathrm{P}<0.05)$ higher in birds fed control and $10 \% \mathrm{INW}$ 
diets than birds fed 20 and $30 \% \mathrm{INW}$ diets.

\section{Discussion}

The average final live weight and weight gained of the broilers were similar up to $20 \%$ level of inclusion of instant noodles waste at the starter phase, beyond which there was a decrease $(\mathrm{P}<0.05)$ in these parameters. Similarity in the final live weight and weight gained of the broilers obtained could be as a result of the heat processing involved in the production of instant noodles. Heat processing (cooking and dry heating) had been reported to reduce the amylase inhibitors, haemaglutinin and phytic acid digestible nutrients available to non ruminant (Emiola and Ologhobo, 2006). Heat processing can also affect physical characteristics of NSP's (Cowieson, et al., 2005; GonzalezAlvarado et al., 2008). This result is contrary to several authors (Annison, 1990; Choct and Annison, 1992). Choct et al. (1992) reported that the use of wheat in poultry is limited because of deleterious effects of NSP.

The depression in final live weight at $30 \%$ inclusion level might be as a result of gut bulkiness due to increased quantity of INW in the diet. The mechanism of action may be related to the ability of insoluble fibre to hold water, thus influencing gut bulk (physical fill) and potentially motility (Aulrich and Flachowsky, 2001). In addition, the reduction in feed intake at this level could be a factor which is evidence in the gross energy of the diets. Feed intake decreased with increase in INW inclusion in the diets. This response agrees with the fact that under ad libitum feeding condition, birds consumed feed primary to satisfy their energy requirements first (Leeson et al., 1996). This observation was in agreement with those of Rabie and Szilagyi (1998). The use of fat as a preservative in the processing of instant noodles associated with higher energy level could also contribute to reduced feed intake of the broilers. Plavnik et al. (1997) reported that the supplemental fat had a marked effect on feed intake, such that feed consumption was $(\mathrm{P}<0.05)$ reduced with increasing dietary energy density.

Dry matter digestibility decreased as INW inclusion in the diets increased at the starter phase while it shows no effect at the finisher stage. Digestibility values of nutrients were higher at the finisher phase than in the starter phase. The trend in age difference is consistent with the fact that the digestive systems of the broilers are not well developed at the starter phase compared with well developed digestive system at the finisher phase. Yasar and Forbes (2000) have reported reduction of intestinal digesta in chicks as early as between 2 and 3 weeks of age. Also the larger retention times in older birds due to the volume of the digestive tract improved digestibility (Palander et al., 2005),

The increased in PCV values as the level of INW inclusion in the diets increased could be as a result of increased in the energy level of the broiler diets with increased inclusion of INW. Energy levels have been found to have a direct relationship with $\mathrm{PCV}$ of the blood (Jain, 1986). The similar $(\mathrm{P}<0.05)$ haemoglobin values recorded from birds fed the control diet and INW based diets is an indication of good oxygen carrying capacity in which the birds are not bound to succumb to any form of respiratory disease. This argument is in line with the findings of Mmereole (1996). Ker et al. (1982) reported that low PCV and haemoglobin are due to iron deficiency. Higher values of haemoglobin and RBC observed for birds fed $30 \%$ INW diet may be as a result of increased quantity of INW in the diet which increased the concentration of the alkaline 


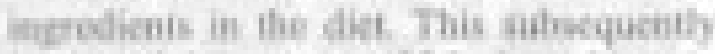

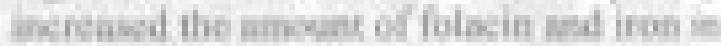

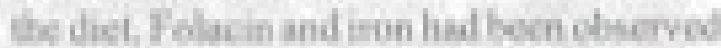

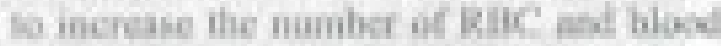

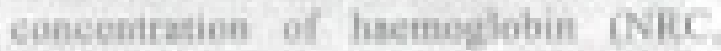

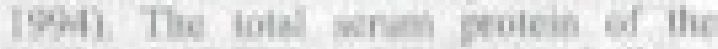

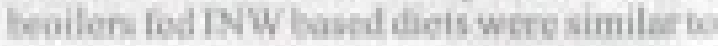

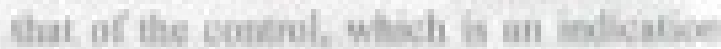
That INW is mintimally amilar to mave

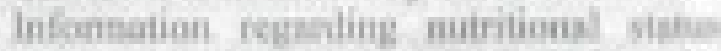

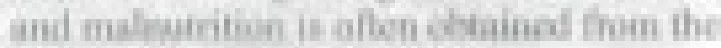

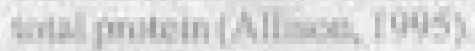

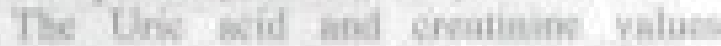

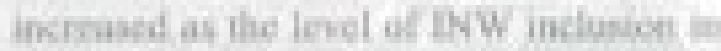

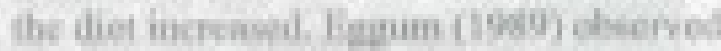

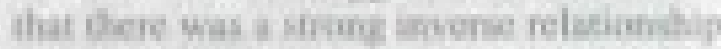

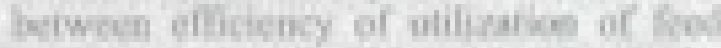

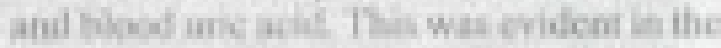
Inal line weith of tha bink which of w

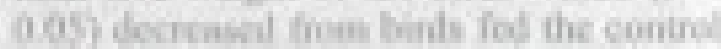

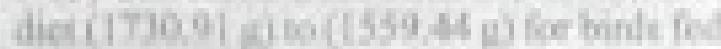
Math IW ilit.

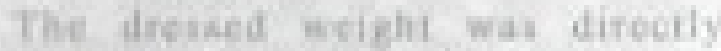

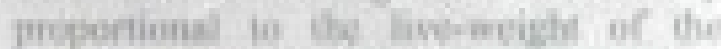

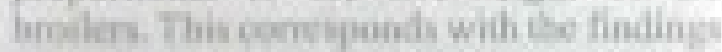

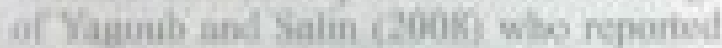

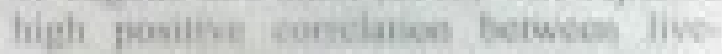

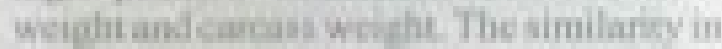

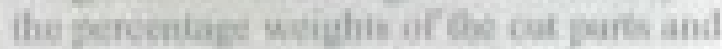

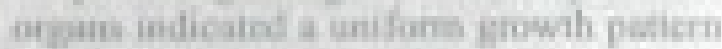

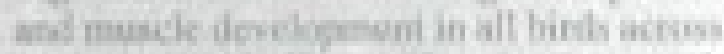

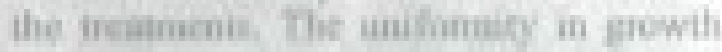

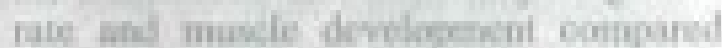

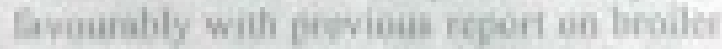

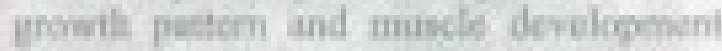

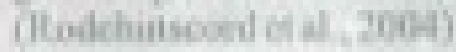

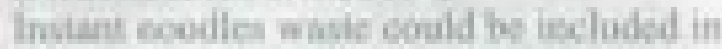

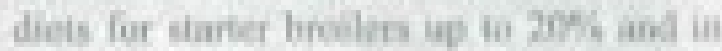

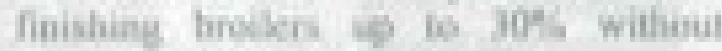

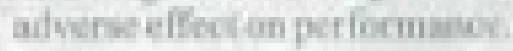

\section{Arelarenter}

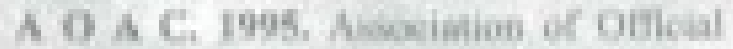

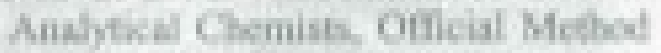

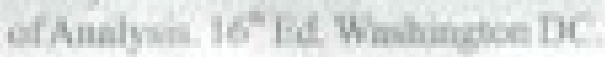

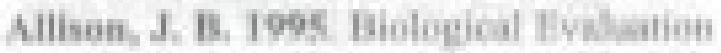

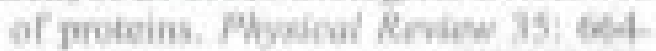
th

Aangan, a, 1990, Polviacohamde

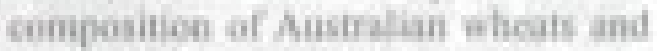
the devenbility of thelr winche in

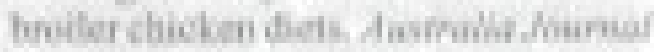

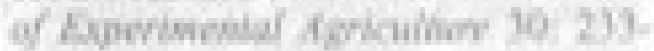
54

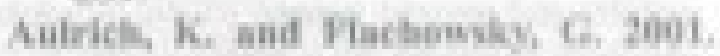

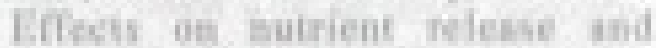

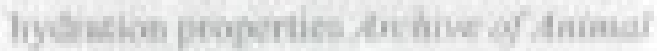

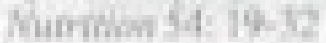

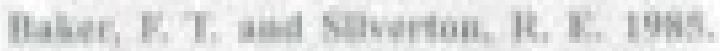

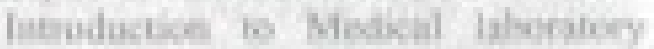

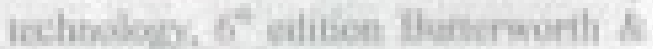

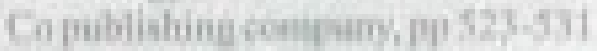

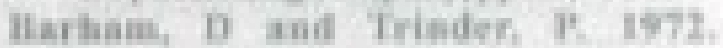

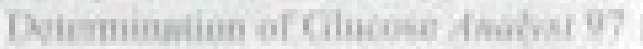

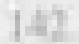

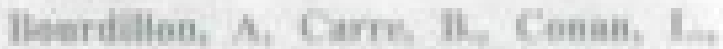

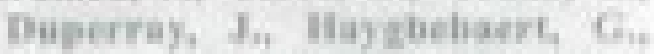

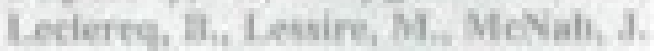

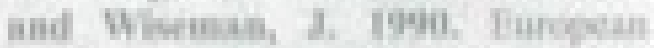

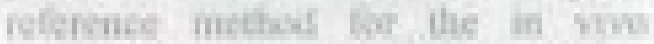

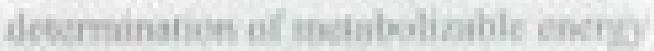

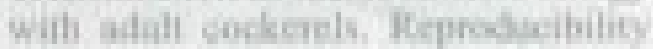

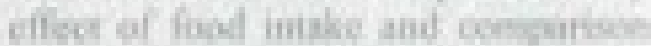

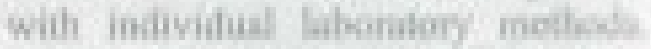

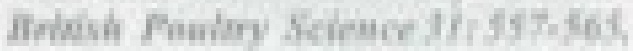

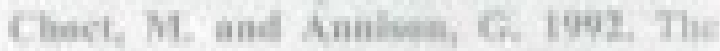

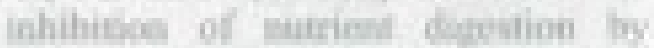

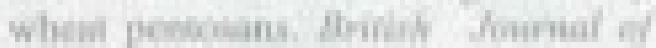

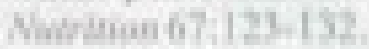

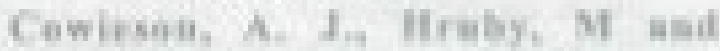

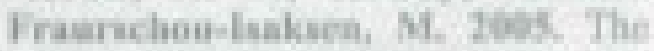

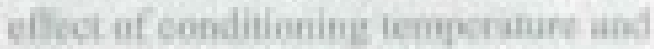

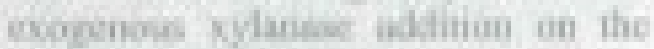

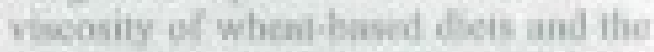

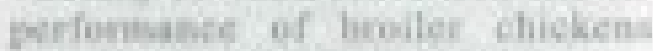

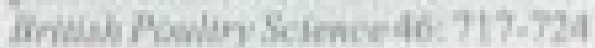

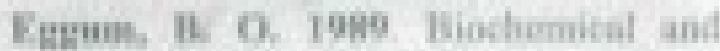

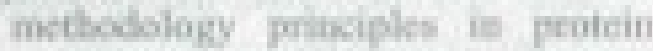

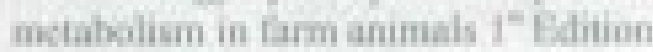

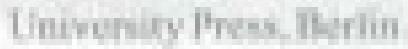


Emiola, I. A. and Ologhobo, Z. A. D. 2006. Nutritional Assessment of raw and differently processed underutilized legume seed in broiler diet Journal of Animal Veterinary Advance 5(2): 96101.

Fossati, P., Prencipe, L. and Berti, G. 1980. Determination of uric acid using enzymatic colorimeter method Clinical Chemistry 26/2.227 231.

Gracia, M. I., Aranibar, M. J., Lazaro, P. $M$ and Mateos, G. G. 2003. Alfaamylase supplementation of broiler diets based on corn. Poultry Science 82: 432-442.

Grant, G. H. 1987. Amino Acids and Proteins: Fundamentals of Saunders Company Philadelphia, USA.328-329.

Gueye, E. F. 2007. Evaluation of the impact of HPAI on family poultry production in Africa. World Poultry Science Journal 63: 391-400..

Henry, R. J. 1974 Colorimetric method of determining Creatinine. Clinical Chemistry., Principles and Tecnics, $2^{\text {nd }}$ edn., Harper and Row, pp 525.

Jain, N.C. 1986. Schalon's veterinary haematology $6^{\text {th }}$ Edition Lea and Fabinger Philadelphia USA pp 178-207

Jones, R., 1984. A standard method of dissection of poultry for carcass analysis. West of Scottland Agricultural College, Technical Bulletin No. 222

Ker, G. R, Lae, E. S, Lan, E. K, Larmor, R. J, Randell E, Forthoter, R. N, Davis, M. A. 1982 . Relationships between dietary and biochemical measures of nutritional status. American Journal Clinical Nutrition 35: 294-308.

Leeson, S., Caston, L. and Yungblut, D. 1996. Adding Roxazyme to wheat diets of chicken and turkey broilers. Journal of Applied Poultry Resources 5:167172.
Mmereole, F. U. C. 1996. Study of Haematological Parameters in the Nigeria local chicken Nigerian Journal of Animal Production 23 (1): 94-97.

NRC 1994. National Research Council. Nutrient requirements of poultry, $9^{\text {th }}$ revised edition National Academy Press, Washington DC

Palander, S., Nasi, M. and Jarvinen, S. 2005. Effect of age of growing turkeys on digesta viscosity and nutrient digestibility of maize, wheat, barley and oats fed as such or with enzyme supplementation. Archive of Animal Nutrition. 59: 191-203.

Plavnik, I., Wax, E. Sklan, D. and Hurwitz, S. 1997. The response of broiler chickens and turkeys to steampelleted diets supplemented with fat or carbohydrates. Poultry Science 76:10061013.

Rabie, M. H., and Szilagyi. M. 1998. Effects of L-carnitine supplementation of diets differing in energy levels on performance, abdominal fat content and yield and composition of edible meat of broilers. British Journal of Nutrition 80:391400.

Reitman, S and Frankel, S., 1957. A Colorimetric Method for the determination of Serum GOT and GPT American Journal of Clinical Pathology 28: 56.

Rodehutscord M, Kapcius M, Timmler R and Dieckmann A. 2004. Linear regression approach to amino acid digestibility in broiler chickens. British Poultry Science, 45: 85-92.

Roeschlau, P., Bernt, E. and Gruber, J.W. 1974. Determination of cholesterol in serum. Clinical Biochemistry 12: 403.

Santos, A. A. Jr, Ferket, P. R, Grimes J. L. and Edens F.W. 2004. Dietary supplementation of endoxylanases and phospholipase for turkeys fed wheat- 
based ration. International Journal of Poultry Science 3(1): 20-32.

SAS Institute. 1999. SAS/STAT User's Guide: Statistics. Version 6. $4^{\text {th }}$ Edition. SAS Institute Inc., Cary, NC.

Weichselbaum, T. E. 1952. Biuret method of determining total protein in serum. American Journal Clinical Pathology 16:40.

WINA. 2010. World Instant Noodles Association. National Trends in Instant $\mathrm{No}$ o d e s D e m a n d s http://instantnoodles.org/noodles/expa nding.market.html.

Yagoub, M. Y. and Salin, A. B. 2008. Effect of compensatory growth on the performance and carcass characteristics of the broiler chicks. Pakistan Journal of Nutrition 7(3): 497-499.

Yasar, S. and Forbes, J. M. 2000. Enzyme supplementation of dry and wet wheatbased feed for broiler chickens: performance and gut responses. British Journal of Nutrition 84: 297-307. 